Intervention

\title{
Interventions: Bringing the decolonial to political geography
}

\author{
Lindsay Naylor $^{\mathrm{a}, *}$, Michelle Daigle ${ }^{\mathrm{b}}$, Sofia Zaragocin ${ }^{\mathrm{c}}$, Margaret Marietta Ramírez ${ }^{\mathrm{d}}$, \\ Mary Gilmartin ${ }^{\mathrm{e}}$ \\ a Department of Geography, University of Delaware, United States \\ ${ }^{\mathrm{b}}$ Department of Geography, University of British Columbia, Canada \\ ${ }^{c}$ Latin American Faculty of Social Sciences (FLACSO-Ecuador), Critical Geography Collective of Ecuador, Ecuador \\ d Department of Geography, University of Washington, United States \\ e Maynooth University, Ireland
}

\section{A R T I C L E I N F O}

Article history:

Received 9 November 2017

Accepted 10 November 2017

Available online 10 January 2018

\section{Interventions: bringing the decolonial to political geography}

Lindsay Naylor, Department of Geography, University of Delaware

Within and outside geography there is a strong interest in the inequities between states and peoples. While work in political geography, particularly in critical and feminist geopolitics, deconstructs discourse and peoples narratives as we seek to understand and represent these inequities, in many cases scholarship remains embedded in western ways of knowing and understanding the world (see: Sharp 2013a,b). Additionally, even as we undertake critical analysis we tend to rely on a discourse of a bifurcated globe, cultivating a problematic north-south divide (Murphy, 2013; see also; Naylor, 2014). This global division largely ignores the geopolitics of knowledge production, as well as the scale of empire, which creates multiple and competing peripheries and signals the need for a reframing or retheorizing that is attentive to multiple and diverse ways of knowing and understanding the world. The main drive of these interventions is to show new ways to incorporate such ways of knowing and being into postcolonial discussions in political geography through decolonial theory.

Imperialism and colonialism are the ways in which 'others' are actively constructed. Yet, the economic, political, and social relations enacted during the conquest and colonial period operated under a system of power still largely present in contemporary

\footnotetext{
* Corresponding author.

E-mail address: Inaylor@udel.edu (L. Naylor).
}

relations between people and states (Quijano, 2007a,b). Engagements with reframing imperialism/colonialism stretch across disciplines. Decolonial theory is rooted in the humanities and more recently is being mobilized in the social sciences and education studies with varying results (on decolonizing education studies see: Tuck \& Yang, 2012). The decolonial operates as an intervention in time and space as it deconstructs the idea of a "post" colonial, which Grosfoguel (2011) and others argue tends to imply an 'end' or 'after' to colonialism and colonial power/knowledge dynamics, while in many cases simultaneously reinforcing similar hegemonic relations (cf. Mignolo, 2000, 2002; Moraña, Dussel, \& Jáuregui, 2008; Tuhiwai-Smith, 1999; Walsh, 2007). Indeed, Walsh notes that "while colonialism ended with independence, coloniality is a model of power that continues" (2007:229). Decolonial theorists argue that colonial power/knowledge dynamics remain embedded in scholarly work and that an encounter and dialogue which reconfigures knowledge production is necessary.

The recognition of the subjugation of knowledge and the creation of artificial difference in the colonial/imperial is part of the project of thinking through the colonial difference, which is put forth by decolonial scholars who seek to dismantle the geopolitics of knowledge and advance knowledge from alterity (cf. Mignolo, 2002). The colonial difference is the site of othering whereby systems of knowledge are hierarchized (Mignolo, 2000). To think from the colonial difference then is to not only acknowledge centuries of imperialism and contemporary 'othering,' but also to recognize and speak from the underside. Thus, contributors to this set of interventions were asked to address the question of how the colonial difference might provide better understandings of political entanglements across space? The broad purpose of this set of interventions is to bring new voices and perspectives to the decolonial through geography, something that we are well-positioned to do as scholars seeking to understand and explain difference across space.

For decades geographers have sought to critically engage an imperial/colonial past. Since the 1990 s postcolonial theory has been deployed by geographers as part of this project (Gilmartin \& Berg, 2007). The use of postcolonial theory in political geography assists with locating the violence of imperialism, empire, state- 
formation, and global trade. In seeking to illuminate the uneven relations between states over time postcolonial scholars attempt to make visible marginalized peoples and places. However, in political geography, the postcolonial is critiqued for relying on, in many cases, western knowledges and a western, post-structuralist canon (e.g. Foucault, Derrida, and Gramsci). Furthermore, as Gilmartin and Berg note, Anglophone postcolonial geographies are "less likely to refer to the writers and theorists of anti-colonial struggles, and more likely to refer to a triad of postcolonial theorists: Edward Said, Homi Bhabha and Gayatri Spivak" (2007:120). It has mostly, if inadvertently, set-up a western/non-western binary that privileges the west. In relying on this canon, political geographers may be construed as using the 'master's tools' to emancipate the 'other' (cf. Koopman, 2008). This theoretical framing and binary thinking tends to neglect the political and economic agency of the so-called 'other,' as well as non-Western ontologies and epistemologies. Indeed, postcolonial political geographies often perpetuate an asymmetrical geopolitics of knowledge, producing studies about the 'other' rather than co-producing knowledge or generating knowledge from within sites of alterity (see: Dowler \& Sharp, 2001, p. 170; Gilmartin \& Berg, 2007).

As early as 2001, Dowler and Sharp recognized the pitfalls of postcolonial theory in political geography arguing: "The experiences of the marginalized are used as the raw materials for postcolonial theories but this does not require an opening of the process of theorizing to the knowledges and wisdom of the marginalized (2001:170)." Sharp (2009) argued for a more critical approach (and removed the oft used hyphen), which examines knowledge production. Such critiques suggest that additional avenues for theorizing political entanglements across space and scale are necessary. These interventions are an attempt to build on/branch out from earlier criticisms of the post- and postcolonial through a decolonial approach. The contributions to this set of interventions use existing critical work, which assists with deconstructing normalizing discourses and also reinvigorates discussion building from work done in the past two decades on the postcolonial and subaltern in geography more generally (cf. Blunt \& McEwan 2003; Coombes, Johnson, \& Howitt, 2013; Escobar, 2001; Gregory, 2004; Koopman, 2011; Radcliffe, 1997; Sharp, 2009, 2011; 2013a,b; Sidaway, 2000; Slater, 2004). The contributing authors offer the decolonial as a way to make visible and address ontological and epistemological violence of scholarship (cf. Sundberg, 2014).

The decolonial requires rethinking/retheorizing from alterity and multiplicity in knowledge production. Put simply, we need more and different perspectives and to more deeply consider privilege over knowledge and where it 'sits.' The decolonial is foremost an attempt to think outside the western canon and western ways of knowing to advance multiple knowledges (Grosfoguel, 2011). A decolonial approach is one that recognizes the differences created by the conquest and perpetuated in contemporary unequal relations between people and states. Grosfoguel argues that viewing the underside of the colonial difference "forces us to look at the world from angles and points of view critical of hegemonic perspectives" (2002:209). Thinking from the colonial difference does not negate western ways of knowing, or specify thinking from a "fixed geopolitical place," but is instead a rethinking of space and time that is multiple and varied (Vallega, 2014, p. 175).

A number of strategies are mobilized by decolonial theorists in thinking from the colonial difference. These approaches include (but are not limited to) relational ontologies, which attempt to erase nature/culture divides (Escobar, 2008); transmodernity, which liberates subjugated knowledges (Dussel \& Mendieta, 1996); border thinking, which implores a rethinking from multiple 'sides' (Anzaldúa, 1987; Mignolo, 2000); and those that theorize a geopolitics of knowledge that (re)considers spaces of knowledge production (Daigle \& Sundberg, 2017; Mignolo, 2002; Naylor, 2017; Walsh, 2007). ${ }^{1}$ These interdisciplinary perspectives offer opportunities to reframe examinations of multi-scalar and multi-sited processes and interstitial spaces from the global to the body. Decolonial analyses make visible the cracks in universals while simultaneously opening up pluriversal spaces.

The decolonial however, does not erase the problems of the postcolonial. This set of writings, while launching an intervention in political geography also provides a platform to critique and reimagine decolonial theory through a geographic lens. While decolonial approaches provide an arena to redirect our thinking, Asher (2013) argues that it does so via conflating the theoretical and the political, which undermines the project. Moreover, the writings in decolonial scholarship are in many cases populated by a heterosexual and heteronormative male gaze (Mendoza, 2015, p. 100; see also: Ramírez's contribution here), sidelining the position of other genders. Compounding this issue is that decolonial theory is very rarely used to engage gender, sexual identity, nature, or economic difference (Asher, 2013; Escobar, 2007; Lugones, 2007; an exception includes the writings of Anzaldúa). How then can we critically engage political questions around identity, race, gender, and sexuality using a decolonial framework? Such political questions are already underway in the sub-discipline, however, a key component of these interventions is to reemphasize calls for scholars to address these questions in a way that is attentive to the geopolitics of knowledge production, which is fundamentally concerned with power. In these ways political geographers can contribute to dismantling colonial/imperial power relations within and beyond the discipline.

In thinking through the aftermath, or the "post" of colonialism, the contributors to this set of interventions advance a number of approaches to think through questions raised by political geographers and to argue for an approach that moves away from universalizing knowledge production and toward many knowledges through attention to: border studies and border thinking, sexuality and gender, settler colonialism and indigenous sovereignty, and embodiment.

Using settler colonialism as an analytical entry point, Michelle Daigle discusses indigenous political geographies and argues for a decolonized approach to indigenous/researcher positionalities. Indigenous sovereignty and futurity form a key feature of this analysis and Daigle urges recognition of, and accountability to, indigenous ways of knowing, understanding, and embodying citizenship, diplomacy, and nation. She pushes for a decolonial praxis that is attentive not only to how we produce knowledge, but how we can simultaneously dismantle colonial/imperial power relations. The decolonial here assists with teasing out the everyday realities of undoing settler colonial experiences.

Sofia Zaragocin notes that the settler colonialism experienced by indigenous peoples globally is not only racialized, but gendered. She notes that the body-politics of a postcolonial world are unevenly written across space. Zaragocin argues for a decolonized feminist geopolitics that is attentive to the plurality of knowledges, genders, and bodies and that is tied to place. Drawing from work in feminist geopolitics and Latin American feminist theory Zaragocin depicts an indigenous, decolonial geography that promotes a bodyterritory. This framing allows for a decolonial feminist geopolitics that is attentive to the violence of subject and territorial formation (particularly as it relates to gender and sexuality) and the

\footnotetext{
1 The Royal Geographical Society theme for 2017 explicitly focused on decolonizing the discipline of geography and two forums discussing the theme were published in anticipation of the conference (see: Noxolo, 2017; Radcliffe, 2017).
} 
invisiblization of difference.

A decolonial approach cannot be in name only and Margaret Ramírez argues that theorizing from place in ways that are embodied-especially with attention to being uninvited settlers on stolen land-is necessary to all decolonial work. Furthermore, to strengthen ties to place and create belonging, strong relations with people must be built. Building on a Chicanx perspective Ramírez imagines a decolonial political geography that allows for a multiplicity of being in and experiencing place. Both Ramírez and Daigle articulate a decolonial praxis, which is a messy process, and raise important questions about accountability for political geographers.

In her contribution, Mary Gilmartin pushes political geographers to move beyond a border ontology, which both challenges and accepts borders and walls and instead consider a border epistemology that opens up the possibilities for examining borders and how we produce knowledge about them both through body- and geo-politics. Decolonizing border studies draws attention to how imperial/colonial power is written in space and time while also through relations between land and people. This is a critical conjuncture as the border continues to be a key site for discussions about the ongoing migrant 'crisis.' Although Mignolo's (2000) concept of border thinking-which is the site of recovery of subjugated knowledges-does not necessarily have to be applied to sovereign borders per se, Gilmartin demonstrates how it can be applied as part of a border epistemology (see also: Gilmartin, 2009).

When we 'write the earth' as scholars we are enacting a form of representation, something that Asher (2017) enunciates as an inherently violent process. As political geographers we are informing on omnipresent body- and geo-politics. In a decolonial (and also feminist) framing representation is not apolitical. Through a decolonial lens we can offer multiple readings and many representations, and the practices, performances, and ways of knowing and understanding the world can be re-inscribed. Together, these interventions offer a number of opportunities to reconsider how we question, research, frame, and represent the postcolonial in political geography.

\section{Embodying relations of accountability in settler colonial contexts}

Michelle Daigle, Department of Geography, University of British Columbia

"Decolonization is accountable to Indigenous sovereignty and futurity"

(Tuck \& Yang, 2012: 3; 35).

The theme of this intervention demands that geographers not only think about, but embody the relational accountability that is tied to living and working on one's own Indigenous territory, or as $\mathrm{a}(\mathrm{n})$ (uninvited) visitor on stolen and occupied Indigenous lands. Further, bringing the decolonial to political geography requires geographers to decolonize knowledge production, academic praxes, structures and institutions (Esson, Noxolo, Baxter, Daley, \& Byron, 2017). More than this, however, if we are to truly center, listen to, and be accountable to Indigenous knowledge on decolonization, "bringing the decolonial to political geography" requires a rupture to the ostensible boundary between scholars, and the positions that scholars embody in settler colonial contexts along the lines of Indigenous-settler, colonized-colonizer, even as the settlercolonizer position is a highly complex and variegated one.

A decolonial praxis urges geographers to think of how their work and everyday practices-scholarly and otherwise-actively dismantle colonial structures and relations of power, while building (re)newed ones that are accountable to the Indigenous political and legal authorities of the lands that many geographers occupy. ${ }^{2}$ In this way, we should think of the theme of these interventions not merely as an intellectual project, but a radical and transformative politics that actively ruptures the colonial political geographies that shape our everyday lives within and beyond the confines of the academy. It is only then that the decolonial can be constructively and radically taken up in political geography, and beyond.

My concern here lies with the colonial difference within settler colonial nations of the so-called "north," such as Canada, the U.S. Australia and New Zealand, which have largely been omitted from political geography's imminent conversations on the decolonial, thus blunting the sub-field's examination of the entanglements of coloniality, Indigenous resistance, and self-determination across the globe. As such, limited attention is directed towards the ongoing dispossession of Indigenous lands, bodies and nationhood in settler colonial contexts, and what decolonization "wants and requires" in such places according to Indigenous peoples (Tuck \& Yang, 2012, p. 2).

Political geography, and the discipline in general, has and continues to be shaped by a large number of academics from the 'north' who examine colonialism in the 'south.' Such an observation is not meant to discount the critical geographic scholarship that examines colonial dispossession and resistance in such places, or to overlook crucial geographical examinations of the re-territorialization of Indigenous space in settler colonial nations (Hunt, 2014; Johnson, 2010; Fabris, 2017). Rather, it is to point out an overwhelming pattern within the discipline, and what appears to be a willingness to examine, discuss and contend with the impacts of colonialism in the places that are removed from one's day-to-day life, even as academics might spend extended periods of time in the 'field' and thus feel deeply connected to those places. $^{3}$

The erasure of settler colonialism and Indigenous resistance and liberation within political geography becomes particularly apparent when one considers the lack of scholarship on decolonial accountabilities to Indigenous peoples in settler colonial contexts, even though the discipline has generated extensive theorizations of geographies of responsibility across multiple scales. With a few exceptions, geographers have mostly grappled with responsibilities to spatially distant neighbors, and spatially proximate strangers along the lines of class (Noxolo, Raghuram, \& Madge, 2012). Meanwhile, there is an absence of the unsettling and discomforting reality of settler colonialism, and what responsibility means in such contexts when one is occupying stolen Indigenous lands, or is connected to such dispossession through the uneven power geometries of global colonial-capitalist development. It is perhaps

\footnotetext{
2 The intended audience for this article are geographers, and academics more generally, who live and work on stolen and occupied Indigenous lands in settler colonial contexts. My intention is not to overlook other forms of colonialism in other contexts, or the experiences of academics in these places. Rather, a focus on stolen and occupied Indigenous territories should bear significance with those living in nations that are not usually defined as settler colonial, something which Zaragocin also alludes to in these interventions as she applies settler colonial theory to the colonial difference in Latin America. Furthermore, the insistence on being accountable to decolonization movements in the places where we live and work bears significance for academics around the globe, including those in Europe, as there is a surge of decolonial activism led by Indigenous and other racialized peoples across various geographies. Finally, the focus on settler colonialism should urge geographers in countries of the 'north' not deemed settler colonial, such as those in Europe, to address how they are connected to ongoing settler colonial dispossession in other countries of the 'north' such as Canada and the U.S.

${ }^{3}$ My intention here is not to discount the unique experiences of academics from the 'south' who have Indigenous and/or genealogical ties to their field site in the 'south', and currently live and work in the global 'north.'
} 
easier to call for geographies of responsibility to colonialism in places where one does not reside, or along the lines of a Marxist class-based analysis, than it is to contend with local Indigenous peoples' demands for decolonization, with all of the messy and uncomfortable political implications involved, including land restitution and socio-political transformation of settler colonial hegemony.

While decolonization is a requirement given the historical and ongoing structure of settler colonialism, it is a radical politics of resistance, reclamation and resurgence that emanates from the longstanding and multiple political and legal orders across diverse Indigenous landscapes. Although variously impacted across space through colonial regimes of dispossession, Indigenous political and legal orders continue to be the foundation of Indigenous sovereignty and futurity, as they are renewed throughout time to account for the realities that shape Indigenous peoples' everyday lives (Coulthard, 2014; Simpson, 2011). Indigenous political and legal orders are not rights and entitlements granted by settler colonial authorities (even though they may be drawn upon to deliberate and negotiate with the settler state), nor are they confined or locked to the space of Indigenous peoples' ancestral territories. Rather, they are mobile and continually renewed as Indigenous peoples' move, from regional to global scales, whether voluntarily or not.

There is an internal politics to decolonization which speaks to the everyday work that Indigenous peoples embody at all scales -including the scale of the intimate- to reclaim and renew political and legal relations of accountability (Hunt, 2015). This entails the regeneration of Indigenous forms of citizenship and internation-al diplomacy through the rebuilding of Indigenous nationto-nation relationships, which defy, refuse and rupture settler colonial boundaries and geopolitical borders (Goeman 2017; Simpson, 2014). As scholars Leanne Betasamosake Simpson (Nishnaabeg) and Heidi Kiiwetinepinesiik Stark (Anishinaabe) elucidate in their respective works, renewing relational accountabilities through the rebuilding of Indigenous kinship relations includes those with non-human kin, such as the land, water and animal nations (Simpson, 2011; Stark, 2010). Moreover, as feminist and queer Indigenous scholars and activists insist, the rebuilding of Indigenous kinship relations must account for how they have been structurally and intimately reshaped through the heteronormative patriarchy of the settler colonial project (Hunt, 2015; Hunt \& Holmes, 2015), which disproportionately impacts Indigenous women, youth, queer, two-spirit and transgendered peoples. Hence, as Zaragocin argues in this intervention, relations of accountability must directly confront colonial patriarchy while rebuilding the gendered and intimate politics of Indigenous sovereignty and futurity. In this way, the rebuilding of Indigenous political relations across nations and clans can only happen if more intimate forms of decolonization are embodied, including the renewal of Indigenous women and two-spirit peoples' political and legal authorities in everyday life, and the self-determined protection of all Indigenous peoples' bodies, as sovereignty over the land is deeply entangled with sovereignty over the body (Women's Earth Alliance and Native Youth Sexual Health Network, 2016).

Decolonial relations of accountability are embodied by Indigenous peoples every day. We recently witnessed this as Indigenous peoples from around the globe travelled far distances to support the Standing Rock Sioux nation's protection of water and refusal of the Dakota Access Pipeline (NYC Stands with Standing Rock Collective, 2016). Further, many Indigenous peoples and those connected to Indigenous communities, witness and embody these relational accountabilities on a daily basis, oftentimes away from the colonial gaze. In all these instances, whether visible or not,
Indigenous women, youth and two-spirit peoples are leading such movements and everyday practices by (re)claiming their legal and political authority, and holding industry, the colonial state, settlers, and their own community members accountable to the ongoing workings of settler colonial capitalism.

Resisting, refusing and resurging against settler colonial violence, however, should never be framed as the sole responsibility of Indigenous peoples who have been embodying relational accountabilities all along. That is, the lack of the decolonial in settler colonial nations is not due to a lack of longstanding Indigenous leadership, nor is it due to a lack of Indigenous peoples constantly demanding accountability amongst one another, and from those occupying their lands. Rather, accountability to Indigenous sovereignties and futurities continues to be denied and refused through capitalist industry and settler governments' ongoing violations of Indigenous law and political orders to secure access and ownership of land, as well as through the structure of white supremacy and "settler moves towards innocence" (Tuck \& Yang, 2012, p. 9).

As Ramirez argues in this intervention, scholars must acknowledge the place from which they theorize the decolonial. This call demands that scholars situate themselves in the unequal power relations that continue to shape, reproduce and legitimate settler colonialism, so that our theorizing reflects everyday embodiments of what decolonization demands from each and every one of us, depending on the location we occupy in the settler colonial project. This call simultaneously demands that we place ourselves on the lands that we live and work on, by knowing the peoples, knowledge systems and political and legal orders that have cared for that land for generations. Personally, my relationship to decolonization is embodied as a Cree woman living in the settler colonial context of Canada. While I am informed by Cree political and legal orders, I am simultaneously mindful of how those orders come into relationship with those of other Indigenous peoples, and specifically those on whose lands I currently live and work onthose of the Musqueam, Squamish and Tsleil-Waututh Nations, in what is otherwise known as Vancouver, British Columbia. Thus, the way I embody the decolonial in the day-to-day must not only be in relation to my own nation's struggles for land and myriad efforts for decolonization. Rather, embodying the decolonial requires that I am a good visitor on other Indigenous nations' territories that I have the privilege to work and live on. And, just as Ramirez does, it requires others living as visitors on diverse Indigenous territories to consider how they are entangled in complex histories and presents of colonial and racialized dispossession, and how they will come into relation with the peoples on whose lands they now find themselves on.

Indeed, questions of relational accountability are complex given the entangled histories of racialized dispossession in settler colonial nations. As Chickasaw scholar Jodi Byrd argues, the forced and violent displacement of various racialized peoples to Indigenous territories should factor into the ways we address and build relations of accountability (Byrd, 2011). How, for example, might radical forms of accountability be built on Indigenous lands, between Indigenous and other racialized communities, to resurge against the proprietary logics of capitalist accumulation and white supremacy, while attending to crucial entanglements of ongoing dispossession and occupation of Indigenous lands? How might these relations of accountability be built not only along the lines of dispossession, but according to longstanding radical traditions of resistance, liberation and freedom across Indigenous and other racialized communities?

Increasingly, relations of accountability between Indigenous 
and other racialized communities are coming to life, as was also made evident at Standing Rock, as well as in Black Lives Matter and No Muslim Ban protests (Kidane \& Martineau, 2013). These relationships urge Indigenous peoples to think about and embody what some Indigenous scholars, such as Glen Coulthard (Dene), call "radical hospitality." Radical hospitality refuses the neoliberal economic logics of the settler colonial border and what Iyko Day calls the "contradictory promise of settler colonial hospitality" (Day, 2016, p. 172) and, instead, renews a hospitality based on Indigenous political and legal orders across diverse Indigenous landscapes. "No bans on Indigenous lands" advocated by Indigenous scholars and activists such as Melanie Yazzie (Dine), urge Indigenous peoples to welcome others into their/our ancestral territories according to Indigenous law, as they become dispossessed of their lands and bodily sovereignty through racial capitalism. And, with this welcoming, comes an accountability to place and its' kin.

As geographers center and learn from Indigenous movements and everyday acts of decolonization, the larger needs and demands of the decolonial should become immediately apparent. The ostensible boundary between academics' professional and personal lives quickly crumbles away as Indigenous peoples demand the dismantling of structural and intimate colonial political geographies, and advocate for the rebuilding of new ones that are accountable to the legal and lawful caretakers of Indigenous lands and waters. Without embodying such radical and transformative accountabilities-as necessarily unsettling, potentially discomforting and contentious as they are-geographers risk reproducing a prevalent trope and buzzword in academia, and the very structures of settler colonialism and white supremacy that we claim to dismantle in our calls for decolonization.

\section{Decolonized feminist geopolitics: coloniality of gender and sexuality at the center of critical geopolitics}

Sofia Zaragocin, Latin American Faculty of Social Sciences (FLACSO-

Within the immense plurality of conversations occurring around decolonization, there are two analytics that place the coloniality of gender and sexuality at their core; Latin American decolonial feminism and settler colonial studies. In this intervention I propose a conceptual alliance between feminist geopolitics and the specific critiques made by Latin American decolonial feminism and settler colonial studies. This approach links the coloniality of gender and sexuality with multi-scalar embodied notions of place-space; in so doing it paves the way towards a decolonial feminist geopolitics. A decolonial feminist geopolitics considers the coloniality of gender and sexuality of imperialistcolonialist state-formations while acknowledging gendered and racialized spatial resistances related to auto-determination or competing notions of sovereignty (indigenous and others). It opens a conversation between critical geopolitics and the plurality of decolonized feminist proposals that are introducing alternative body-land based epistemologies, ontologies and geopolitics.

As a feminist geographer situated in the global south, I am purposefully engaging with geographically diverse literature that converge on placing sexuality and coloniality at the center of multiscalar embodied accounts of spatial resistance. Latin American scholarship rarely takes up settler colonial studies and Anglophone feminist geopolitics neglects Latin American decolonial feminist work. Intellectual alliance-building is key to decolonizing feminist geopolitics, making it truly plural in its geographic reach and not just relevant to a "global north" audience. Decolonial feminist geopolitics is not meant only to decolonize Anglophone feminist geopolitics, but also address present day gender coloniality in postcolonial spaces. It is in connecting the different existing decolonial discussions and praxis already in place, that a decolonial feminist geopolitics can take on many forms and as such its relevance be more widespread.

In what follows, I situate feminist geopolitics as the most appropriate form of existing critical geopolitics for the conceptual conversation I am proposing. This analysis is followed by a discussion of the coloniality of gender and sexuality analysis in Latin American decolonial feminism and settler colonial studies that, in convergence with Anglophone feminist geopolitics, results in a decolonized feminist geopolitics. This serves as an example; it is by no means the only decolonized feminist geopolitics possible.

The multi-scalar analytic of feminist geopolitics offers an entry point from which to analyze geopolitical and geo-economic relations (Massaro \& Williams, 2013) in relation to everyday experience and structural violence. Feminist geopolitics scales down to the intimate, emphasizing the corporal experience of power determined by place (Naylor, 2017), with particular emphasis on racialized gender and sexualized spaces (Massaro \& Williams, 2013). Recent work concerning intimate geopolitics highlights bodies, and specifically, women's reproductive functions as contentious sites over which territories and geopolitical disputes are negotiated (Smith, 2012), an important analysis for indigenous women facing ethnic attrition and cultural appropriation under settler colonialism. Furthermore, the focus of feminist geopolitics on fear and violence across scales determined by embodied experience (Smith \& Pain, 2008) opens-up discussions of colonial violence on racialized gendered and sexualized bodies and places, which are likewise emphasized in Latin American decolonial feminism.

Nevertheless, despite the endless possibilities for conceptual engagement, feminist geopolitics carries an Anglophone tradition based on universal western concerns, ontologies and epistemologies (Naylor, 2017). Engaging with Latin American decolonial feminism and settler colonialism will build feminist geopolitics as mechanism for investigating difference (Naylor, 2017, p. 28), and I would add, difference based on the coloniality of gender and sexuality as expressed by Latin American and settler colonial studies scholars. The emphasis of feminist geopolitics on the intimate and everyday lived experience of individuals and communities furthers the possibility of thinking through the colonial difference (Dixon, 2015; Naylor, 2017), permitting strategic liaisons between literature. If, as Massaro and Williams state, feminist geopolitics unpacks geopolitical power to the everyday scale while allowing for a resistance that challenge dominant state power (2013:567), then a decolonized feminist geopolitics is both possible and desirable. Additionally, a decolonial feminist geopolitics strengthens feminist geopolitics from 'below' while speaking to more dominant strains of geography.

If a coloniality of gender is place dependent, then a decolonized feminist geopolitics must also be. Latin American decolonial feminism builds on postcolonial feminism to emphasize the coloniality of gender defined by the fact that gender relations, like race, were created in and by the colonial encounter and are still present at the very intersections of gender/class/race in contemporary Latin American societies characterized by postcolonial intersectional hierarchies (Lugones, 2010; Radcliffe, 2015). This feminist framework extends earlier work of Black feminism and Third World feminism, in alliance with indigenous and Afro-descendent Latin American feminist's interpretation of the region's relation of coloniality/modernity (Curiel, 2007; Espinosa-Miñoso, Correal, \& Muñoz, 2014). In doing so, Latin American decolonial feminism bridges different scholarly critiques of coloniality (Critical Indigenous studies, postcolonialism/post-colonialism, modernity/coloniality/decoloniality), promoting a plurality of epistemologies, 
political alliances and embodied ontologies. Place is important in this feminist construction, whereby Abya Yala, an Indigenous decolonial imagined geography of the region offers a site to promote alternatives and spaces of struggle (Zaragocin, 2017). Abya Yala, in the Kuna language, is the pre-conquest name of contemporary Latin America: a utopic territory (González, 2012:13), a counter-geography (Castaño, 2007 in González, 2012), and a geopolitics of the past and present within counter-hegemonic positions (Espinosa-Miñoso et al., 2014, p. 6). ${ }^{4}$

Abya Yala is a geopolitics that reaffirms pre-conquest territory and a desired futurity of decolonized space in which Indigenous and Afro-descendent women's politics are encouraged and created. ${ }^{5}$ Abya Yala space serves as an imagined counter-geography defined from a plurality of feminist positions that seek metaphorical and material politics of decolonization (Zaragocin, 2017). As such, Abya Yala is an epistemological and geopolitical place of decolonial feminism and it is from this place of enunciation that embodied ontologies are promoted. Cuerpo-Territorio (Body-Territory) for example, has become a central tenet of contemporary Latin American feminist theory and politics based on Indigenous ontologies of space and decolonial understandings of the gendered body. It is a decolonized embodied ontology. Cuerpo-territorio places the community and territory as a single subject of political agency that resists and identifies violations against women's bodies and territories as part of the same process (Cabnal 2014; Miradas Criticas del Territorio desde el Feminismo, 2017). This merging of body and space questions hegemonic feminisms on the one hand, and on the other, furthers discussions of the possibility of a decolonial turn in political geography. For Anglophone feminist geopolitics, Latin American decolonial feminisms envelop multiple peripheral geographies (postcolonialism, Black feminism, Chicano feminism, Indigenous feminism, and communitarian feminism) from which to further create new conceptual alliances that facilitate decolonization. Abya Yala highlights the importance place can also have in creating alternative epistemologies, while the example of the embodied ontology of cuerpo-territorio demonstrates how decolonization calls for alternative epistemologies that create or engage other ontologies. As such, Latin American decolonial feminism affirms both a specific geopolitics and multiple feministsituated epistemologies. What settler colonial studies can add to this framework is attention to the link between present-day Indigenous elimination and the coloniality of gender and sexuality; it is a historicized approach that speaks to the attrition and slow death of racialized women in Latin America. Weaving different place-based decolonial feminist perspectives together maximizes their epistemic and geopolitical potential.

For settler colonial studies, decolonization starts with acknowledging how gender and sexuality are embedded in the continuing colonization of Indigenous peoples and the promulgation of European modernity by modern-day settlers (Morgensen, $2010 ; 2012$ ). The coloniality of gender and sexuality is the main condition in the formation of gender, sexualized and modern queer subjects, cultures, politics and spatial imaginaries in the United States and other settler states (Morgensen, 2010). Central to these discussions is the structural logic of Indigenous 'elimination' through amalgamation and territorial replacement (Wolfe, 1994, 1999) and the indigenization of settlers whereby settlers appear as naturally belonging to Indigenous land through legal, cultural or violent processes of forced territorial dispossession (Morgensen, 2012; Veracini, 2010; 2011). Decolonizing requires exploration of

\footnotetext{
${ }^{4}$ An indigenous group that lives in Panama and Colombia. 5 Bi-yearly regional gatherings of indigenous women of the Abya Yala are held in
different countries of Latin America.
}

the contemporary colonial conditions of everyday life that are naturalized under settler colonialism. As Morgensen states "the indigenization of settlers and the universalization of the west are one" (2012:13) based on gendered and sexualized power relations we call 'settler colonialism"' (Morgensen, 2012). Racialized sexuality and gender are not side subjects but part of a larger history that conditions contemporary forms of coloniality (Morgensen, 2012). These discussions are particularly pertinent with regards to decolonized spatial constructions of auto-determination and Indigenous sovereignty whereby Native autonomy threatens national territorial and jurisdictional imagery even when Indigenous territoriality and governance precedes the state (Rifkin, 2009). Like feminist geopolitics, settler colonialism studies is conceptualized at the everyday scale through attention to what Rifkin (2014) calls 'settler colonial common sense.' Surprisingly though, feminist geopolitics seldom engage with the settler colonialism literature despite the immediate consequences of contemporary forms of Indigenous elimination and settler indigenization. Conversely, Native studies scholars are utilizing critical geopolitics scholarship to further analysis of spatial injustice and Native feminist practices, connecting multi-scalar analysis with gendered and sexualized violence in settler states (Goeman, 2017).

Latin American decolonial feminism and settler colonial studies take into account gender and sexuality at the core of their analyses, indicating that embodied decolonized approaches are underway. When these intellectual traditions are ignored, such silences resonate with Sundberg's critique of posthumanist geography and its Eurocentric silence on the location and epistemologies of Indigenous peoples (2014). In this way, it is not up to political geography and critical geopolitics to 'discover' and determine new ways of decolonizing place and bodies; these embodied everyday experiences are already occurring and being theorized in these places and by those previously considered subaltern. Much as Koopman's celebrated alter-geopolitics pointed to a geopolitics from below (Koopman, 2011), this piece suggests a different approach for critical geopolitics to understand coloniality as dependent on place. A decolonial feminist geopolitics requires engaging with existing traditions that invoke decolonized feminist notions of place and embodied epistemologies. The ability and humility of feminist political geographers to gather knowledge and praxis from what is already happening and re-elaborate existing feminist geopolitics will determine the course of decolonization in critical geopolitics. Latin American decolonial feminism is an important feminist framework from which an emerging geopolitics is occurring, and key for further developing a decolonial feminist geopolitics. In this case, the responsibility lies with Anglophone feminist geopolitics, but wide-spread conversation on existing decolonized epistemologies and geopolitics across diverse geographies is beneficial for all involved. A decolonized feminist geopolitics does not stay silent about the role of coloniality of gender and sexuality in defining contemporary subject formation and spatial imaginaries that provoke cultural and physical elimination of Indigenous others. Rather it engages fully with these decolonial traditions.

\section{Reckoning with decolonial praxis}

\section{Margaret Marietta Ramírez, Department of Geography, University of Washington}

Decolonization must mean attending to ghosts, and arresting widespread denial of the violence done to them. Decolonization is a recognition that 'a ghost is alive so to speak. We are in relation to it and it has designs on us such that we must reckon with graciously' (Tuck \& Ree, 2016:647, citing Gordon, 1997:64).

As an epistemology and as a practice, the decolonial resists and 
rewrites colonial conceptions of land and embodiment. If colonialism denotes the conquest of land and the dispossession and erasure of Indigenous peoples, then to decolonize is to reconnect and re-embody the relationship to land. In this piece, I tease out the decolonial from the intersections of North American Indigenous genealogies and Chicanx feminist epistemologies. ${ }^{6}$ While the decolonial theory that often gets taken up in geography stems from the Latin American context, I intentionally choose not to center these in my analysis for I am deterred by the masculinist framings of the decolonial in these literatures, and how the writings of Indigenous and Third World Feminist genealogies are often considered accessorial citations rather than engaged with as theories in their own right. ${ }^{7}$ Therefore, in this piece, I draw primarily from Indigenous and Chicanx feminist theorizing to argue for a decolonial epistemology and practice that is embodied in place. ${ }^{8}$ This decolonial praxis, I argue, insists upon accountability from academics as embodied subjects, in their writing and in their practice. As Ananya Roy elucidates, "to speak is to speak from a place on the map ... and yet theory is so often characterized by its disembodied voice and unmarked location" (2015: 201). We all theorize from our experience, and yet it is only those who make their experience visible in their theorizing that are accused of "identity politics," while whiteness and masculinity remain unmarked and unquestioned voices of authority. In the following I consider how, by speaking their position and implicating their work in place, scholars may engage in a decolonial praxis. How might an accountability to the places we reside and our relationships to the peoples that live and have origins there, create expanded notions of place, and relationality in the colonial present? And how might academic praxis extend beyond the page to be accountable to the countless crises underway, as Daigle and Gilmartin attest to in their pieces, as these words are written?

Decolonial praxis is not something simple to engage - to practice decolonial accountability is politically and emotionally fraught yet invaluable work. Like anti-racist praxis, it is a process, a state of becoming. As I center decolonial epistemologies from North American Indigenous genealogies, I will first outline the decolonial from the site of North American settler colonialism, and then go on to consider how Chicanx feminist conceptions of the decolonial are both complimentary and at times incongruous to Indigenous theorizations. If settler colonialism is the conquest and ongoing occupation of land and erasure of Indigenous peoples from and their relationships to that land (Barker, 2012; Grande, 2013; Wolfe, 1999), the decolonial then is ultimately the re-appropriation of land in a way that centers Indigenous resurgence and confronts the hauntings of coloniality (Alfred 2005; Corntassel, 2012; Coutlhard 2014; Simpson, 2011). This makes decolonization in a settler colonial state such as the United States, from where I am born and situated, especially fraught, for, "empire, settlement, and internal colony have no spatial separation ... [which makes] settler colonialism in the U.S. context ... a site of contradictory decolonial desires" (2012:7). As Tuck and Yang explain, the settler colonial

\footnotetext{
${ }^{6}$ Chicanx is a term that stands in for Chicano/a, in which the $\mathrm{X}$ is a means to ungender the Spanish language and make the identity inclusive of female, male and gender-non-conforming identities.

7 I engage with decolonial theories that might fall into what Maldonado-Torres describes as the "third premise" of the Decolonial Turn that "in its skepticism and attitude, are arguably most at home in spaces such as ethnic studies and gender and women's studies departments in the Western academy and ... among decolonial activists, independent scholars and artists across the entire spectrum of Global South, including the south in the north." (2011:1). While I am an admirer of Maldonado-Torres' work, once more Third World Feminist and Indigenous theorists are framed as afterthoughts to the masculinist project of the "Decolonial Turn."

${ }^{8}$ Here I follow Sara Ahmed's declaration: "Feminism is at stake in how we generate knowledge; in how we write, in who we cite" (2017:14).
}

state functions to uphold white supremacy, and was formed through the enactment of Indigenous dispossession and Black enslavement and landlessness. Therefore, the decolonial in the American settler colonial context requires a political commitment to decolonization, the acknowledgement of one's fraught position as a settler on Indigenous lands and the end goal of the repatriation of land. A decolonial practice must also be attentive to antiblackness and how plantation logic remains a function of coloniality (McKittrick, 2013; Woods, 1998), and decolonial work needs to function in tandem with abolitionist visions of borderless futures.

This fraught space of contradictory decolonial desires "implicates and unsettles" in a way that, while difficult, carries political possibility in how it demands that one be attentive to their embodied implication in settler colonialism. If academics are to harken the decolonial in their theorizing, I argue that there is a need to take on a decolonial accountability in this work. The decolonial requires a re-embodiment, an acknowledgement of the space from which we theorize, and how our location within the colonial project too shapes the theorizing and politics we exude. When the decolonial becomes metaphor, contradictory decolonial desires are allowed to co-exist without requiring accountability. This makes decolonization into an empty signifier, and, I argue, perpetuates the disembodied voice of theory. More and more the decolonial is becoming a buzz word in academia (Tuck \& Yang, 2012), the way 'social justice' is used to represent any deconstructive efforts to re-frame/re-envision power structures. There is danger in the appropriation, co-optation, and domestication of the decolonial ( Esson et al., 2017; Noxolo et al., 2012; Tuck \& Yang, 2012), and I argue that to prevent this slippage into metaphor, scholars can locate their theories from their position in the place they reside. As example, I will now delve into my own engagement with decolonial literature how this relates to my positioning within the stolen and occupied territory called the United States.

As a Chicanx scholar-activist, my own position amidst these contradictory decolonial desires is complex. I was initially drawn into decolonial epistemologies through Chicanx feminist theory, which has been critiqued as slipping too deeply into decolonial metaphor without being accountable to Indigenous theorizations. The writings of Gloria Anzaldúa (1987), Emma Pérez (1999), Chela Sandoval (2000) and many others, theorize how Chicanx and Latinx peoples imagine and create decolonial spaces from the same colonial fissures that dismember us. Colonialism created the fissured mestizx body, offspring of both colonizer and colonized, and the migration across national borders further complicate the Latinx' relationship to land and place, belonging neither here nor there. While fraught, this in-betweenness makes possible a differential consciousness, enabling mestizxs to weave between and among places, creating imaginaries beyond rigid notions of nation and identity (Sandoval, 2000). The space of possibility that mestizxs build from their fissured identities creates a third space that is represented by the borderlands (Anzaldúa, 1987), where a decolonial imaginary emerges (Pérez, 1999) and new epistemologies are imagined. ${ }^{9}$ Chicanx feminist theory spoke to me not only in how I saw my own identity imagined and empowered on the page, but in how from the colonial fracturing of bodies and land was born a space of possibility - a decolonial space. And from this embodied space, Chicanx decolonial theories emerged; theories that spoke from a place on the map, the in-between space of the U.S.-Mexico borderlands that many Chicanxs inhabit. The decolonial desires of Chicanx feminism are, however, not always

\footnotetext{
9 This imagining resonates with Gilmartin's conversation in these interventions on border epistemologies.
} 
harmonious with Indigenous decolonization projects, nor do Chicanx/Latinx peoples always fit neatly into the position of settlers (Barker, 2012; Byrd, 2011).

The challenge in where Chicanx feminist theory and the Chicanx/Latinx positionality is situated amid the settler colonial state, is in their mestizx positioning, and their differential experiences within and of the settler state. ${ }^{10}$ Latinx are racialized in a multitude of ways, from Afro-Latinx to Indigenous-Latinx to white-passing Latinx; this diversity gives Latinx' complex positionalities that complicate conceptions of settlers. Chicanx feminist theory, particularly Anzaldúa's writing, is critiqued as appropriating and at times over-simplifying Indigenous epistemologies. Yet, as Keating contests in Anzaldúa's posthumous publication, Light in the Dark, "Anzaldúa does not claim an authentic indigenous practice but instead develops a decolonizing ontology" in which she articulates how our imagination and our situatedness in in-between spaces enable us to re-invent reality (2015: xxxiii-xxxiv). In this sense, the decolonial ontology that Anzaldúa and many Chicanx scholars employ, channels the landlessness that Anzaldúa reflects upon, takes up the space of in-betweenness that Chicanx navigate, and sculpts a space of transformative possibility from this placelessness. This placelessness becomes less metaphorical and even more urgent as I write these words, the day that a fraudulent administration in the U.S. has revoked the Deferred Action for Childhood Arrivals (DACA) immigration policy, and Dreamers are left violently in flux. These are the day-to-day embodied politics of decolonial work, and this is where efforts to build solidarity amidst decolonial desires may face an uneasy, but healthy, friction. Decolonial praxis, as I mentioned at the beginning of this piece, is a process: how might we bring conflicting decolonial desires into conversation while remaining accountable to the Indigenous project of decolonization?

The decolonial holds abundant possibility in how by being accountable to Indigenous epistemologies, one cultivates a grounded or embodied relationship to the land. The feeling of landlessness or placelessness I experience is something inherent to the ideologies of the settler state I live in, embedded in the white supremacist myths of Manifest Destiny and melting pots. These settler-colonial myths have instilled in Americans a racial-capitalist relationship to place, in which white supremacy requires that Indigenous, Black, and other people of color remain dispossessed from the land. Yet by engaging in a decolonial politics that is accountable to Indigenous land rights, we enrich our sense of placed-ness and belonging. By coming to terms with the ways that we inhabit and produce space, with how we are embodied, we build richer relationships to the land and to peoples in relation to us. A politics of decolonial accountability is something to be practiced in tandem with abolitionism, with the struggles of undocumented peoples, with movements for liberation. These struggles may have competing or contradictory decolonial desires, but fraught conversations are necessary to envision decolonial futures.

A decolonial praxis requires re-embodiment, interrogating one's relationship to colonialism, racial capitalism and the land we live upon. A reckoning of the ghosts that haunt us. By this I mean that decolonial theorizing and decolonial politics require an attention to how we inhabit space, require us to be accountable to our fraught interrelations to all beings and to the land itself, regardless of

\footnotetext{
${ }^{10}$ Zaragocin furthers this conversation in these interventions, discussing how decolonial feminism considers the coloniality of gender and sexuality amid settler colonial states.

11 "It was cultural anxiety that drove white working class voters to Trump: A new study finds that fear of societal change, not economic pressure, motivated votes for the president among non-salaried workers without college degrees" (Green, 2017: np).
}

positionality. Perhaps this argument will cause 'cultural anxiety' for many geographers, as was found to be the primary reason white Americans voted for Trump in 2016, ${ }^{11}$ but I urge scholars to not fall back upon a possessive investment in whiteness (Lipsitz, 1998), or a possessive investment in "universal grammars" (Roy, 2015). ${ }^{12}$ Rather, I encourage scholars to reckon with their ancestral histories and to act with a sense of accountability to decolonial futures. To "radically embody" decolonization, as Daigle argues in this intervention, by rupturing white supremacy and settler colonialism in all aspects of their praxis. If all scholars theorized and acted with accountability from the place they reside, with an attention to that place, its histories, and one's interrelations, how might praxis be radically reimagined? How might theorizing be more engaged in the urgent politics we reside in and a decolonial praxis of accountability enacted?

\section{Beyond walls: border epistemologies and the politics of migration}

\section{Mary Gilmartin, Maynooth University, Ireland}

We are living through a contemporary migration crisis, though the contours of that crisis are blurred. From one perspective, the crisis is understood as the dangers that migrants endure as they seek refuge from war, conflict, or poverty. From another perspective, the crisis is the perceived threat that migrants pose to the stability of states. In both cases, numbers intensify the strength of the reaction: the numbers dying on the Mediterranean crossing to Europe; or the numbers 'flooding' into the US, the UK, France, Hungary, or any of the other states where politicians are exploiting migration flows for electoral expediency. Within political geography, both the contemporary migration crisis and migration more generally are based on border ontologies, which take the existence of borders as an accepted starting point. This has important, and limiting, consequences for how we see migration and migrants. In this short piece, I argue for the importance of decolonial thought specifically the concept of border thinking - for our understanding of migration, particularly because it illuminates and challenges the primacy of border ontologies.

In political geography, border ontologies are evident in the significant body of work that focuses on borders and walls. This focus includes the growing number of physical walls that are being built to mark state boundaries, such as the razorwire fence along Hungary's border with Serbia, or the planned 30-foot-high border wall between the US and Mexico (Minca \& Rijke, 2017). It also includes the sites away from state boundaries where borderwork is increasingly taking place, such as "corridors, camps and spaces of confinement" (Jones \& Johnson, 2016:1). In all of this work, borders and walls are "symbolic and material manifestations of political boundaries" (Till et al., 2013:52). Borders and walls also provide a clear focus for political geographers concerned with the contemporary migration crisis, whether that crisis is framed in terms of enabling or restricting migration. In the face of the crisis, the materiality of borders and their consequences for migrants have again taken center stage, whether this is the securitisation of migration through enhanced and often militarised border controls (Léonard, 2010), or the "violent consequences for migrants" (Jones \& Johnson, 2016, p. 187). As Reece Jones suggests, it is difficult to imagine life without borders (Jones, 2016, p. 186). This matters for migrants, because of the way in which borders "have become inextricable from migration” (De Genova, 2013, p. 253). A border

\footnotetext{
12 See Van Sant and Bosworth's (2017) intervention on the need for radical geographers to engage with the politics of rural and working class whiteness.
} 
ontology thus reinforces what Harsha Walia names as border imperialism: "the entrenchment and reentrenchment of controls against migrants" (2013:38). While critical research highlights the how and speculates on the why of border imperialism, it also serves to assert, again, the colonial difference.

The colonial difference is the starting point for understanding how border ontologies work, and how they might be challenged. To begin, borders and walls represent the colonial difference, defined by Walter Mignolo as "the space where the coloniality of power is enacted" (Mignolo, 2000:ix). Maria Lugones insists on making visible the violence of coloniality in "the powerful reduction of human beings to animals, to inferiors by nature" (Lugones, 2010, p. 751 ), a statement that will resonate with the work of critical scholars of migration (see Vaughan-Williams, 2015). Yet, Mignolo's understanding of the colonial difference is not limited to a unidirectional operation of power. Instead, Mignolo also sees the colonial difference as the site from where border thinking can emerge: "the space where the restitution of subaltern knowledge is taking place" (2000:ix-X). Mignolo's border thinking echoes the earlier work of Gloria Anzaldúa, who described the new consciousness that can emerge from what she calls the Borderland (Anzaldúa, 1987:9-101). The Borderland, "vague and undetermined ... in a constant state of transition" (Anzaldúa, 1987:3) is the colonial difference: the space where power is enacted and where restitution can take place.

How might thinking from the colonial difference change how we understand political entanglements, like migration, across space? My argument is that rather than accepting border ontologies as inevitable, we should instead use a border epistemology to address both the contemporary migration crisis and migration more generally. Despite the best efforts of critical scholars to expose the politics of borders and bordering practices, they are constrained by the inevitability that a border ontology implies. In contrast, a border epistemology - or border thinking, to use Mignolo's term moves beyond this inevitability to suggest an alternative geopolitical imaginary and future.

Border thinking - "the moments in which the imaginary of the modern world system cracks" (Mignolo, 2000, p. 23) - thus provides an explicit challenge to the border ontologies that shape our understanding of migration. It does so in three key ways. First, it takes on the categorization and hierarchization that is integral to border ontologies. Second, it draws connections between those who are affected by the dominance of border ontologies, specifically those who are placed 'outside.' Third, it offers an alternative to a contemporary global politics that "gives us two renditions of life and a being rendered by them" (Lugones, 2010, p. 751). The migrant is central to border thinking because of the role of "immigrant consciousness" in providing that alternative (Mignolo, 2011, p. 274. See also: Anzaldúa, 1987:99-101). As an example, Ramírez (these interventions) shows the power of immigrant consciousness in her discussion of Chicanx/Latinx in-betweenness in the United States.

The process of categorization creates hierarchies of humans. Anzaldúa asserted this as central to the creation of borders, set up "to distinguish us from them" (1987:3). Quijano argued that it was central to coloniality, particularly through the lasting effects of the social classification of the world's population by race (Quijano 2007a,b). These hierarchies are clearly evident in the politics of migration management, where people are distinguished on the basis of ascribed attributes such as race, and on the basis of learned behaviours such as 'highly-skilled' (Anderson, 2013). Critical migration researchers challenge this through an emphasis on the border. As De Genova points out, "if there were no borders, there would be no migrants" (2013), while Bauder argues for both open borders and no borders $(2013 ; 2017)$. Calls for the removal of borders begin to challenge border ontologies, because they suggest that borders are socio-spatial constructions and thus not inevitable. However, these calls are less useful in articulating a border epistemology, because they do not challenge the practices of differentiation - particularly racial and ethnic differentiation - that underpin border ontologies. Specifically, the removal of borders is not sufficient for the end of hierarchization, a significantly more entrenched process. As Grosfoguel et al. (2015) point out, the ongoing categorization of the migrant "problem" in Western societies has clear roots in the colonial era. Identifying and highlighting the lasting and pernicious effects of hierarchization in relation to humans and human mobility provides a starting point for border thinking.

The second, more radical, approach to border thinking requires us to recognize what Mignolo calls the body-politics and the geopolitics of knowledge production: the claims to universality of certain types of local knowledge production, and the denial of the significance of other forms of local knowledge. Border thinking links together those who have been marginalized in this process; it acts as "a connector between different experiences of exploitation" (Mignolo, 2007, p. 498). In relation to migration, border thinking thus foregrounds what Mignolo calls immigrant consciousness: specifically, the grounded geo- and body-politics of knowledge that originates in one place and is dispersed elsewhere. Mignolo is particularly concerned with migrants from what he calls "the Third World", rather than migrants who are more privileged on the basis of race or place of birth. However, the focus on immigrant consciousness - particularly on what Mignolo describes as "worldsensing" (2011:276) - allows for a more expansive understanding of border thinking. Specifically, it emphasises commonalities in experiences, emotions and thinking that move beyond categorisations and hierarchies of migrants and non-migrants. The implications of this are clear in the work of Harsha Walia (2013), who blends together academic, movement, and experiential knowledge in a powerful call for decolonization. In particular, Walia's discussion of No One Is Illegal (NOII) - a migrant justice movement in Canada - emphasises the importance of solidarity between migrants of color and Indigenous people, and between migrants and the labour movement (2013:97-156).

The third approach to border thinking is future-oriented. Mignolo describes this as the decolonial option: the emergence of a delinked "global political society" (2011:280). Walia argues for decolonization, which she describes as "the imagining and generating of alternative institutions and relations" (2013:249). Regardless of the different ways of framing this future-oriented approach, a key aspect is the prioritization of the experiences, perspectives, and insights of those - like migrants - who occupy the colonial difference. As Mignolo suggests, "for a white European body to think decolonially means to give" (2011:280). That act of giving, which could also be framed as giving way or giving up, is challenging for those - western academics included - who are used to framing their insights as global, while disregarding the local geopolitics of their own knowledge production.

In arguing for border thinking, Mignolo is at pains to insist that it is not an attempt to create a new global or "abstract universal" (2011:282). Instead, he argues that it is an alternative, pluri-versal vision, where many worlds will exist (2007:499). Here, it will be possible to consider - as many political geographers do today - the material and symbolic significance of borders and walls, and the performance of bordering. But that is not enough. A border ontology accepts life with borders, or struggles to imagine life without them, even when the nature or performance of those borders is challenged. A border epistemology, in contrast, highlights the borders of our current geo- and body-politics, and the ways in which they dehumanize humans as migrants (Lugones, 
2010). Through border thinking, which happens from the colonial difference, we can begin to imagine and make our world, and the place of migrants, very differently.

\section{Conflicts of interest}

\section{There is no conflict of interest.}

\section{References}

Ahmed, S. (2017). Living a feminist life. Duke University Press.

Alfred, T. (2005). Wasáse: Indigenous pathways of action and freedom. Peterborough, Ont: University of Toronto Press.

Anderson, B. (2013). Us and Them?: the dangerous politics of immigration control. Oxford: United Kingdom: OUP Oxford.

Anzaldúa, G. E. (1987). Borderlands: The new mestiza = La frontera. San Francisco, Calif: Aunt Lute Books.

Anzaldúa, G. (2015). Light in the Dark/Luz en lo Oscuro: Rewriting Identity, Spirituality, Reality. Durham: Duke University Press.

Asher, K. (2013). Latin american decolonial thought, or making the subaltern speak. Geography Compass, 7(12), 832-842.

Asher, K. (2017). Notes for a postcolonial feminist marxist engagement with alternatives to development. In Presented at the annual meeting of the $A A G$, boston, MA. http://meridian.aag.org/callforpapers/program/AbstractDetail.cfm? AbstractID $=79302$.

Barker, A. J. (2012). Locating settler colonialism. Journal of Colonialism and Colonial History, 13(3).

Bauder, H. (2013). Nation, 'migration' and critical practice: Nation, ‘migration' and critical practice. Area, 45(1), 56-62.

Bauder, H. (2017). Migration borders freedom. NY: Routledge.

Blunt, A., \& McEwan, C. (2003). Postcolonial geographies. Bloomsbury Publishing.

Byrd, J. A. (2011). The transit of empire: Indigenous critiques of colonialism. Minneapolis: University of Minnesota Press.

Cabnal, L. (2014). Documento en Construcción para aportar a las reflexiones continentales desde el feminismo comunitario, al paradigma ancestral originario del Sumak Kawsay-Buen Vivir. Sumak Kawsay"-Buen Vivir" (02/02/2014).

Castaño, P. (2007). América Latina y la producción transnacional de sus imágenes y representaciones. Algunas perspectivas preliminares. In D. Mato, \& F. Maldonado (Eds.), Cultura y Transformaciones sociales en tiempos de globalización. Perspectivas latinoamericanas. Buenos Aires: CLACSO.

Coombes, B., Johnson, J. T., \& Howitt, R. (2013). Indigenous geographies II: The aspirational spaces in postcolonial politics - reconciliation, belonging and social provision. Progress in Human Geography, 37(5), 691-700.

Corntassel, J. (2012). Re-envisioning resurgence: Indigenous pathways to decolonization and sustainable self-determination. Decolonization: Indigeneity, Education \& Society, 1(1), 86-101.

Coulthard, G. S. (2014). Red skin, white Masks: Rejecting the colonial politics of recognition. Minneapolis: Minnesota Press.

Curiel, O. (2007). Crítica poscolonial desde las prácticas políticas del feminismo antirracista. Nómadas, 26, 92-101.

Daigle, M., \& Sundberg, J. (2017). From where we stand: unsettling geographical knowledges in the classroom. Transactions of the Institute of British Geographers. https://doi.org/10.1111/tran.12201.

Day, I. (2016). Alien capital: Asian racialization and the logic of settler colonial capitalism. Durham: Duke University Press.

De Genova, N. (2013). 'We are of the connections': Migration, methodological nationalism, and 'militant research.'. Postcolonial Studies, 16(3), 250-258.

Dixon, D. P. (2015). Feminist Geopolitics: Material states. Ashgate Publishing, Ltd.

Dowler, L., \& Sharp, J. (2001). A feminist geopolitics? Space and Polity, 5(3), 165-176.

Dussel, E. D., \& Mendieta, E. (1996). The underside of modernity: Apel, Ricoeur, Rorty, Taylor, and the philosophy of liberation. Atlantic Highlands, N.J.: Humanities Press.

Escobar, A. (2001). Culture sits in places: Reflections on globalism and subaltern strategies of localization. Political Geography, 20(2), 139-174.

Escobar, A. (2007). Worlds and knowledges otherwise. Cultural Studies, 21(2-3), $179-210$.

Escobar, A. (2008). Territories of difference: Place, movements, life, redes. Durham: Duke University Press.

Espinosa-Miñoso, Y., Correal, D. G., \& Muñoz, K. O. (2014). Tejiendo de otro modo: Feminismo, epistemología y apuestas descoloniales en Abya Yala. Popayán: Universidad del Cauca.

Esson, J., Noxolo, P., Baxter, R., Daley, P., \& Byron, M. (2017). The 2017 RGS-IBG chair's theme: Decolonising geographical knowledges, or reproducing coloniality? Area, 49(3), 384-388. https://doi.org/10.1111/area.12371.

Gilmartin, M. (2009). Border thinking: Rossport, Shell and the political geographies of a gas pipeline. Political Geography, 28(5), 274-282.

Gilmartin, M., \& Berg, L. D. (2007). Locating postcolonialism. Area, 39(1), 120-124.

Goeman, M. (2017). Ongoing storms and struggles. Gendered violence and resource exploitation. In J. Barker (Ed.), Critically Sovereign: Indigenous gender, sexuality, and feminist studies (pp. 70-99). Durham: Duke University Press.

González, A. C. (2012). Mujeres Indígenas constructoras de región: desde América Latina hasta Abya Yala. Scientific Journal of Humanistic Studies, 4(6).
Gordon, A. (1997). Ghostly matters: haunting and the sociological imagination. Minneapolis: University of Minnesota Press.

Grande, S. (2013). Accumulation of the primitive: The limits of liberalism and the politics of Occupy Wall Street. Settler Colonial Studies, 3(3-4), 369-380.

Green, E. (2017, May 9). It was cultural anxiety that drove white, working-class voters to Trump. The Atlantic. Retrieved from https://www.theatlantic.com/ politics/archive/2017/05/white-working-class-trump-cultural-anxiety/525771/.

Gregory, D. (2004). The colonial present: Afghanistan, Palestine, Iraq. Malden, MA Wiley-Blackwell.

Grosfoguel, R. (2002). Colonial difference, geopolitics of knowledge, and global coloniality in the modern/colonial capitalist world-system. Review - Fernand Braudel Center for the Study of Economies, Historical Systems, and Civilizations, 25(3), 203-224.

Grosfoguel, R. (2011). Decolonizing post-colonial studies and paradigms of political Economy: Transmodernity, decolonial thinking, and global coloniality. Transmodernity, 1(1), 1-36.

Grosfoguel, R., Oso, L., \& Christou, A. (2015). 'Racism', intersectionality and migration studies: Framing some theoretical reflections. Identities, 22(6), 635-652.

Hunt, S. (2014). Ontologies of indigeneity: The politics of embodying a concept. Cultural Geographies, 21(1), 27-32.

Hunt, S. (2015). Violence, law and the everyday politics of recognition: Comments on glen Coulthard's red skin, white masks. In , Vol. 20. Annual meeting of the native American and indigenous studies Association, Washington, DC.

Hunt, S., \& Holmes, C. (2015). Everyday decolonization: Living a decolonizing queer politics. Journal of Lesbian Studies, 19(2), 154-172.

Johnson, J. T. (2010). Place-based learning and knowing: Critical pedagogies grounded in indigeneity. Geojournal, 77(6), 829-836.

Jones, R. (2016). Violent borders: Refugees and the right to move. NY: Verso.

Jones, R., \& Johnson, C. (2016). Border militarisation and the re-articulation of sovereignty. Transactions of the Institute of British Geographers, 41(2), 187-200. https://doi.org/10.1111/tran.12115.

Kidane, L., \& Martineau, J. (2013, October 29). Building connections across decolonization struggles. Roar Magazine. Retrieved from https://roarmag.org/essays/ african-indigenous-struggle-decolonization/.

Koopman, S. (2008). Imperialism Within: Can the Master's tools bring down empire? ACME: An International E-journal for Critical Geographies, 7(2), 283-307.

Koopman, S. (2011). Alter-geopolitics: Other securities are happening. Geoforum, $42(3), 274-284$.

Fabris, M. (2017). Decolonizing neoliberalism? First Nations reserves, private property rights, and the legislation of indigenous dispossession in Canada. In M. H. Bruun, P. J. Cockburn, B. S. Risager, \& M. Thorup (Eds.), Contested property claims: What disagreement tells us about ownership (1st ed., pp. 185-204). Abingdon, Oxon, UK; New York: Routledge.

Léonard, S. (2010). EU border security and migration into the european union: FRONTEX and securitisation through practices. European Security, 19(2), 231-254.

Lipsitz, G. (1998). Possessive investment in whiteness. Philadelphia: Temple University Press.

Lugones, M. (2007). Heterosexualism and the colonial/modern gender system. Hypatia, 22(1), 186-209.

Lugones, M. (2010). Toward a decolonial feminism. Hypatia, 25(4), 742-759.

McKittrick, K. (2013). Plantation futures. Small Axe, 17(3), 1-15. https://doi.org/10. 1215/07990537-2378892.

Maldonado-Torres, N. (2011). Thinking through the decolonial turn: Postcontinental interventions in theory, philosophy, and critique-an introduction. Transmodernity, 1(2).

Massaro, V. A., \& Williams, J. (2013). Feminist geopolitics. Geography Compass, 7(8), 567-577.

Mendoza, B. (2015). Coloniality of gender and power. The oxford handbook of feminist theory. Oxford University Press.

Mignolo, W. (2000). Local histories/global designs: Coloniality, subaltern knowledges, and border thinking. Princeton, N.J: Princeton University Press.

Mignolo, W. (2002). The geopolitics of knowledge and the colonial difference. The South Atlantic Quarterly, 101(1), 57-96.

Mignolo, W. (2007). Delinking. Cultural Studies, 21(2-3), 449-514.

Mignolo, W. D. (2011). Geopolitics of sensing and knowing: On (de)coloniality, border thinking and epistemic disobedience. Postcolonial Studies, 14(3), 273-283.

Minca, C., \& Rijke, A. (2017). Walls! Walls! Walls!. Retrieved April 20, 2017 http:// societyandspace.org/2017/04/18/walls-walls-walls/.

Miradas Criticas del territorio desde el Feminismo. (2017). Mapeando el CuerpoTerritorio. Guía Metodológica para Mujeres Que Defienden Sus Territorios. Quito, Abya Yala.

Moraña, M., Dussel, E. D., \& Jáuregui, C. A. (2008). Coloniality at large: Latin America and the postcolonial debate. Durham: Duke University Press.

Morgensen, S. L. (2010). Settler Homonationalism: Theorizing settler colonialism within queer modernities. GLQ: A Journal of Lesbian and Gay Studies, 16(1-2), 105-131.

Morgensen, S. L. (2012). Theorising gender, sexuality and settler Colonialism: An introduction. Settler Colonial Studies, 2(2), 2-22.

Murphy, A. B. (2013). Advancing geographical understanding: Why engaging grand regional narratives matters. Dialogues in Human Geography, 3(2), 131-149.

Naylor, L. (2014). "Some are more fair than others": Fair trade certification, development, and north-south subjects. Agriculture and Human Values, 31(2), $273-284$. 
Naylor, L. (2017). Reframing autonomy in political geography: A feminist geopolitics of autonomous resistance. Political Geography, 58, 24-35.

Noxolo, P. (2017). Introduction: Decolonising geographical knowledge in a colonised and re-colonising postcolonial world. Area, 49(3), 317-319. https://doi.org/10. 1111/area.12370.

Noxolo, P., Raghuram, P., \& Madge, C. (2012). Unsettling responsibility: Postcolonial interventions. Transactions, 37(3), 418-429. https://doi.org/10.1111/j.1475-5661. 2011.00474.x.

NYC Stands with Standing Rock Collective. (2016). \#StandingRockSyllabus. Retrieved from https://nycstandswithstandingrock.files.wordpress.com/2016/10/ standingrocksyllabus7.pdf.

Pérez, E. (1999). The decolonial Imaginary: Writing chicanas into history. Bloomington: Indiana University Press.

Quijano, A. (2007a). Coloniality and modernity/rationality. Cultural Studies, 21(2), $168-178$.

Quijano, A. (2007b). Questioning "race." Socialism and Democracy, 21(1), 45-53.

Radcliffe, S. A. (1997). Different heroes: Genealogies of postcolonial geographies. Environment and Planning a, 29(8), 1331.

Radcliffe, S. A. (2015). Dilemmas of difference: Indigenous women and the limits of postcolonial development policy. Durham: Duke University Press.

Radcliffe, S. A. (2017). Decolonising geographical knowledges. Transactions of the Institute of British Geographers, 42(3), 329-333. https://doi.org/10.1111/tran. 12195.

Rifkin, M. (2009). Indigenizing Agamben: Rethinking sovereignty in Light of the "peculiar" status of native peoples. Cultural Critique, 73(1), 88-124.

Rifkin, M. (2014). Settler common sense: Queerness and everyday colonialism in the American renaissance. University of Minnesota Press.

Roy, A. (2015). Who's afraid of postcolonial theory? International Journal of Urban and Regional Research.

Sandoval, C. (2000). Methodology of the oppressed. Minneapolis, MN: Minnesota Press.

Sharp, J. (2009). Geographies of postcolonialism. SAGE.

Sharp, J. P. (2011). A subaltern critical geopolitics of the war on terror: Postcolonial security in Tanzania. Geoforum, 42(3), 297-305.

Sharp, J. P. (2013a). Geopolitics at the margins? Reconsidering genealogies of critical geopolitics. Political Geography, 37(0), 20-29.

Sharp, J. P. (2013b). Reply: Thinking through marginality. Political Geography, 37, $36-37$.

Sidaway, J. D. (2000). Postcolonial geographies: An exploratory essay. Progress in Human Geography, 24(4), 591-612.

Slater, D. (2004). Geopolitics and the post-colonial: Rethinking North-South relations. Malden, Mass.: Blackwell Pub.

Simpson, L. (2011). Dancing on our turtle's back: Stories of nishnaabeg re-creation, resurgence and a new emergence. Winnipeg, Man: Arbeiter Ring Pub.

Simpson, A. (2014). Mohawk interruptus: Political life across the borders of settler states. Durham: Duke University Press.

Smith, S. (2012). Intimate geopolitics: Religion, marriage, and reproductive bodies in Leh, Ladakh. Annals of the Association of American Geographers, 102(6),
$1511-1528$.

Smith, S. J., \& Pain, R. (2008). Fear: Critical geopolitics and everyday life. In Fear: Critical geopolitics and everyday life (pp. 1-24). Burlington, VT: Routledge.

Stark, H. (2010). Respect, responsibility, and renewal: The foundations of Anishinaabe Treaty Making with the United States and Canada. American Indian Culture and Research Journal, 34(2), 145-164.

Sundberg, J. (2014). Decolonizing posthumanist geographies. Cultural Geographies, 21(1), 33-47.

Till, K. E., Sundberg, J., Pullan, W., Psaltis, C., Makriyianni, C., Zincir Celal, R., et al. (2013). Interventions in the political geographies of walls. Political Geography, 33, 52-62. https://doi.org/10.1016/j.polgeo.2012.11.005.

Tuck, E., \& Ree, C. (2016). Glossary of haunting. In S. H. Jones, T. E. Adams, \& C. Ellis (Eds.), Handbook of Autoethnography (pp. 639-658). Walnut Creek, Calif: Routledge.

Tuck, E., \& Yang, K. W. (2012). Decolonization is not a metaphor. Decolonization: Indigeneity, Education \& Society, 1(1), 1-40.

Tuhiwai-Smith, L. (1999). Decolonizing methodologies: Research and indigenous peoples. New York: Zed Books.

Vallega, A. A. (2014). Latin american philosophy from identity to radical exteriority. Indiana University Press.

Van Sant, Levi, \& Bosworth, Kai (2017). Race, rurality, and radical geography in the US. Antipode Interventions. https://antipodefoundation.org/2017/09/14/racerurality-and-radical-geography/amp/.

Vaughan-Williams, N. (2015). "We are not animals!" Humanitarian border security and zoopolitical spaces in Europe. Political Geography, 45, 1-10.

Veracini, L. (2010). Settler colonialism: A theoretical overview. NY: Palgrave Macmillan.

Veracini, L. (2011). Introducing: Settler colonial studies. Settler Colonial Studies, 1(1), $1-12$.

Walia, H. (2013). Undoing border imperialism. Oakland, CA: Institute for Anarchist Studies.

Walsh, C. (2007). Shifting the geopolitics of critical knowledge. Cultural Studies, 21(2-3), 224-239.

Wolfe, P. (1994). National and miscegenation: Discursive continuity in the post Mabo era. Analysis: The International Journal of Social and Cultural Practice, 32-152.

Wolfe, P. (1999). Settler colonialism and the transformation of anthropology: The politics and poetics of an ethnographic event. London: Cassell.

Women's Earth Alliance and Native Youth Sexual Health Network. (2016). Violence on the. Land, violence on our bodies: Building an indigenous response to environmental violence (pp. 1-116). Berkeley, California, USA; Toronto, Canada: Women's Earth Alliance and Native Youth Sexual Health Network. Retrieved from http://landbodydefense.org/uploads/files/VLVBReportToolkit2016.pdf.

Woods, C. A. (1998). Development arrested: the blues and plantation power in the Mississippi Delta. London; New York: Verso.

Zaragocin, S. (2017). Feminismo decolonial y buen vivir en feminismos y buen Vivir: Utopias descoloniales. Universidad de Cuenca. 